УДК $347.45 / .47$

DOI

\author{
О. М. Котенко \\ orcid.org/0000-0002-5777-0626 \\ завідувач відәілу професійної підготовки та післядипломної освіти \\ Комунального закладу вищої освіти «Одеська академія неперервної освіти Одеської обласної ради»
}

\title{
ПРАВОВЕ РЕГУЛЮВАННЯ ДОГОВОРУ ПРО НАДАННЯ ОПЛАТНИХ ОСВІТНІХ ПОСЛУГ У СФЕРІ ВИЩОЇ ОСВІТИ
}

Постановка проблеми. Надання оплатних освітніх послуг є найпоширенішою прибутковою діяльністю освітніх організацій. Правове регулювання надання платних освітніх послуг має комплексний характер і здійснюється нормами не тільки законодавства про освіту, а й іншими галузями. Такий договір насамперед регулюється Законом України «Про освіту» [1] та законом України «Про вищу освіту», де передбачено, що підставою для зарахування особи на навчання $\mathrm{e}$ виконання вимог Умов прийому на навчання для здобуття вищої освіти, правил прийому й укладання договору про навчання між закладом вищої освіти й вступником. [2] Але крім законодавства про освіту такий договір регламентується й іншими галузями, і тому правова природа такого договору викликає велику кількість суперечок.

Аналіз останніх досліджень і публікацій. Питанням надання оплатних освітніх послуг займалось багато науковців, зокрема А.А. Баталова, Р.Ю. Білоусова, Д.В. Деревянко, Ю.В. Громко, Л.Я. Данилова, І.О. Голоденко, С.В. Древінг, Я.А. Єфімович, С.В. Куров, Л.М. Волчанська, але комплексного аналізу правової природи такого договору не було надано.

Метою статті є аналіз правової природи договору надання оплатних освітніх послуг у закладах вищої освіти.

Виклад основного матеріалу. Правовою формою надання оплатних освітніх послуг є договір на надання освітніх послуг. Правова природа такого договору викликає багато суперечок.

Питання про правову природу договору на надання оплатних освітніх послуг викликало цілу палітру поглядів. Найпоширеніша думка про те, що договір належить до цивільноправових і підпадає під регулювання глави 63 Цивільного кодексу України (далі - ЦК України) [3]. Окремі автори категорично відкидають цивільноправовий характер відносин між студентом і вищим навчальним закладом із надання освітніх послуг. І.О. Голоденко, один із представників такої позиції, таким чином обґрунтовує відсутність цивільноправової природи договору на надання оплатних освітніх послуг. Якщо допустити існування договору на надання оплатних освітніх послуг між студентом і вишем, то це означає, по-перше, що на відповідні відносини повинен поширюватися Закон України
«Про захист прав споживачів», згідно з яким клієнт може вимагати в тому числій відшкодування моральної шкоди; по-друге, професор, який читає лекцію з кафедри, - вже не професор у звичному розумінні цього слова, а послугонадавач; по-третє, студента за невиконання навчального навантаження вже не можна відрахувати адміністративним актом - наказом ректора або декана, тому що це буде одностороннім розірванням цивільноправового договору, тобто навчальному закладу доведеться в суді вимагати розірвання договору, посилаючись на його грубе порушення іншою стороною [4].

Такі аргументи проти цивільноправової природи договору на надання оплатних послуг викликають певне здивування. Зокрема, не зрозуміло, через які причини на відносини між освітнім закладом і студентом не може поширюватися Закон про захист прав споживачів, тим більше норми про компенсацію моральної шкоди, оскільки цілі придбання освіти в громадян різноманітні: отримання загальнопрофесійної освіти, цілісного уявлення про професію, підвищення культурного й духовного рівня, розширення кругозору і так далі. Отримання освіти з метою стати професійним підприємцем не виключає вищезгадані мотивації. I це доводить, що за освітою громадяни йдуть, керуючись насамперед особистими інтересами. Щодо другого зауваження, слід сказати, що професор, який читає лекції, не перебуває в договірних відносинах зі студентом, він знаходиться в трудових відносинах із навчальним закладом, через які й надає освітні послуги студенту. Що стосується відрахування студента за невиконання навантаження, то детальніше про це буде сказано нижче.

Окремі вчені доводять приналежність правовідносин між особами, які навчаються, і освітньою установою, що випливають із договору на надання оплатних освітніх послуг, до педагогічного права через заперечення їх цивільноправового характеру. Наприклад, Д.В. Деревянко вважає, що відносини між освітнім закладом і студентами регулюються методом адміністративного права, тобто між ними встановлюються відносини субординації. Аргументи проти цивільноправової конструкції договору на надання оплатних освітніх послуг зводяться до такого: 
1) договір більш схожий на публічний договір, проте за ст. 633 ЦК України право на підписання публічного договору належить підприємцю;

2) змістом договору надання послуг є вчинення дій виконавцем за завданням замовника, а замовник зобов'язується оплатити послуги (ст. 901 ЦК України), тобто обов'язок замовника обмежується лише оплатою послуг. Проте в договорі про здійснення послуги також одночасно є зобов'язання щодо освоєння освітньої програми [5].

Дійсно, відповідно до ст. 633 ЦК України як зобов'язана сторона публічного договору виступає підприємець. Однак, на наш погляд, це прикре упущення законодавця, тому що некомерційні організації під час здійснення ними підприємницької діяльності можуть також укладати договори, правовий режим яких аналогічний режиму публічних договорів. Другий аргумент автора, на наш погляд, абсолютно невиправданий, тому що ні в одній формулі цивільноправового договору законодавець ніколи не прагнув викласти всі права й обов'язки його учасників. Мало того, визначення договору про надання послуг, наведене в ст. 901 ЦК України, має загальний характер, тому що неможливо врахувати в одній дефініції особливості всіх типів договорів на надання оплатних послуг.

Л.Я. Данилова також розглядає відносини з надання платних освітніх послуг як педагогічні, які, на її погляд, не регулюються ні цивільним, ні адміністративним, ні трудовим правом. Цивільноправовий характер платних освітніх послуг автор заперечує з таких причин:

1) в договорі на надання освітніх послуг від замовника потрібно вчинення ряду активних дій (відвідування лекцій, семінарів, виконання навчального плану і так далі), тоді як згідно зі ст. 901 ЦК України від замовника потрібна лише оплата за надані послуги;

2) особа, яка навчається, повинна підкорятися вказівкам органу управління освітньою установою, зазнавати заходів дисциплінарного стягнення, що не відповідає принципу рівності й незалежності в цивільних відносинах;

3) договір на надання платних освітніх послуг уважається обов'язковим не з моменту його укладення, а з моменту оплати навчання;

4) студент позбавлений традиційного для цивільних правовідносин права оскаржувати якість освіти й стягувати зазнані збитки [6].

Заперечення по першому аргументу були викладені вище. Щодо інших доводів, слід зазначити таке. По-перше, між особами, які навчаються, і вишем після видання наказу про зарахування встановлюються різноманітні відносини, до яких належать у тому числі й адміністративні. Тому наявність відносин влади й підпорядкування не впливає на цивільноправовий характер договору. По-друге, відповідно до ЦК України договір набирає чинності й стає обов'язковим для сторін із моменту його укладення. А укладеним він вважається 3 того моменту, коли між сторонами досягнуто згоди з усіх істотних умов договору, до яких належать також і умови, щодо яких за заявою однієї зі сторін має бути досягнуто згоди. По-третє, предметом договору на надання оплатних освітніх послуг є в тому числі діяльність із надання освітніх послуг, а не дія. У зв'язку із цим виконання договору здійснюється поетапно й розтягнуто в часі. По-четверте, право учнів на оспорювання якості освітніх послуг безпосередньо випливає iз загальних норм ЦК України й норм глави 63 ЦК України, які в субсидіарному порядку застосовуються до договорів на надання оплатних послуг.

Відкидаючи цивільноправовий характер відносин між освітнім закладом і студентом із приводу надання оплатних освітніх послуг, Л.М. Волчанська водночас не заперечує цивільноправову природу договору на надання оплатних послуг в рамках додаткової освіти. Відмінність між цими договорами, на її погляд, полягає в тому, що в першому випадку в договорі йдеться про освіту (яка містить як навчання, так і виховання); у другому випадку - тільки про навчання [7]. Освіта відрізняється від навчання у формі додаткової освіти тим, що:

1) вона здійснюється відповідно до державного освітнього стандарту;

2) має цілеспрямований і системний характер;

3) виховання в освітньому процесі має самостійне значення поряд із навчанням;

4) обов'язковим компонентом освітнього процесу постає підсумкова атестація учнів;

5) навчання завершується видачею диплома про відповідну освіту й (або) кваліфікацію.

Такі доводи викликають заперечення, оскільки договір на надання оплатних освітніх послуг виступає як самостійний тип цивільноправового договору, всередині якого виділяються види й різновиди, наділені певною специфікою. Такі особливості має і договір на надання додаткових освітніх послуг, який виступає як вид договору на надання оплатних освітніх послуг.

Окремі автори також вважають, що конструкція договору про надання оплатних освітніх послуг, передбачена главою 63 ЦК України, прийнятна тільки для платних додаткових освітніх послуг, що надаються державними й муніципальними освітніми установами; платною освітньою діяльністю недержавних освітніх установ; індивідуальною трудовою педагогічною діяльністю. Платна ж освітня діяльність, здійснювана державними й муніципальними освітніми установами в рамках державного освітнього стандарту, повинна здійснюватися в рамках договору про підготовку фахівця з вищою освітою. Такий договір розглядається ними як змішаний договір, що 
поєднує елементи різних галузей права, але з переважанням квазітрудовими (трудовими) відносинами. Водночас норми трудового права повинні застосовуватися до таких відносин за аналогією. В обгрунтування цього висновку наводяться такі аргументи: по-перше, особа, яка навчається (абітурієнт), приймається в освітній заклад на основі конкурсного випробування (тестування, співбесіда) шляхом видання наказу про зарахування (за аналогією - працівника); по-друге, із цього моменту студент повинен дотримуватися правил внутрішнього розпорядку, розкладу занять і інших локальних актів (для працівника також); по-трете, за невиконання зазначених вище актів застосовуються заходи дисциплінарного впливу, аж до відрахування (для працівника також); по-четверте, за хорошу успішність (роботу) студента можна заохочувати підвищеною стипендією (для бюджетників) (для працівників - грошовою премією); по-п'яте, для багатьох категорій працівників (службовців) проводиться атестація для визначення відповідності рівня знань, а також курси підготовки й підвищення кваліфікації. Для переходу студента на другий курс необхідна також проміжна атестація, яка врешті-решт визначає відповідність рівня знань, умінь і навичок вимогам, що пред'являються освітніми програмами й навчальними планами; по-шосте, наявність у того, хто навчається, і працівника відпустки (канікул); по-сьоме, навчання в певних освітніх установах входить у трудовий стаж та інше.

Якщо думка автора про виділення договору підготовки фахівця з вищою освітою в окрему групу договорів з-поміж договорів на надання оплатних освітніх послуг ще піддається сприйняттю, то висновок про правову природу такого договору викликає подив, хоча, можливо, він і оригінальний. Незважаючи на так звану «схожість», між роботою та навчанням лежить велика прірва, i застосовувати до цих інститутів однаковий правовий механізм вкрай було б помилковим. Крім того, навчання в освітній установі не включається до трудового стажу.

Інші автори, не визначаючи правову природу договору на надання оплатних освітніх послуг, відзначають, що:

1) характерною рисою договору про оплатне навчання в державному виші є поєднання влади й рівноправ'я;

2) за змістом прав та обов'язків сторін такий договір не відповідає умовам договору на надання оплатних послуг.

Водночас подібні взаємини не можна назвати суто адміністративно-правовими, оскільки багато в чому вони мають взаємний характер.

Поширена думка про адміністративно-правовий характер відносин між особами, які навчаються, і освітнім закладом. 3 цієї позиції заслуговує на особливу увагу думка С.В. Курова, який вважає, що відносини між учнями й адміністрацією вишу певною мірою рівноправні [8]. Адміністрація не тільки володіє управлінськими правами, але має і певні обов' язки щодо учнів (забезпечувати учням безкоштовне користування лабораторіями, кабінетами, аудиторіями, читальними залами, бібліотеками й іншими навчальними й навчально-виховними закладами, спортивними базами й іншим обладнанням навчальних закладів). У відносинах же між педагогом та учнем переважає елемент рівноправності, хоча є й управлінський елемент.

На наш погляд, договір на надання оплатних освітніх послуг є складним інститутом, що поєднує елементи цивільноправового й адміністративно-правового регулювання 3 переважанням цивільноправових засад. Такий висновок підтверджується через аналіз предмета договору й характеру відносин, що випливають із нього. Специфіка предмета договору на надання оплатних освітніх послуг виражається в його неоднорідному складі. Предмет договору містить два елементи: освітню діяльність і нематеріальний результат такої діяльності у вигляді набутих знань, умінь, навичок. Відносини, що випливають із діяльності по наданню освітньою установою освітніх послуг (проведення лекцій, семінарських і практичних занять, консультацій, іспитів, заліків і так далі) є майновими; відносини з приводу набутих знань, умінь, навичок за своєю правовою природою належать до особистих немайнових відносин, пов'язаних із майновими (останні відносини є підставою їх виникнення). Висновок про характер останніх відносин зумовлений тим, що знання, вміння, навички є особистими нематеріальними благами, вони не віддільні від особистості їх носіїв, не передаються, крім того, вони не підлягають грошовій оцінці. Грошовій оцінці підлягає освітня діяльність, а результат такої діяльності, так само як i здоров'я, є неоціненним особистісним капіталом. Якщо особа, яка отримала освіту, отримує доходи за допомогою набутих знань, умінь, навичок, то мову вже треба вести про самостійні відносини, що випливають із права громадянина на працю, на заняття підприємницькою діяльністю.

Правовідносини, що безпосередньо випливають зі здійснення освітньої діяльності, є цивільноправовими, тому що суб'єкти таких відносин, по-перше, наділені юридичною рівністю; по-друге, майново відокремлені; по-третє, мають автономну волю (вони не залежать від волі контрагента в ухваленні рішення та його здійсненні).

Відносини з приводу придбаних студентами знань, умінь, навичок збагачують предмет цивільного права, тому що в науці такої галузі права до немайнових відносин, пов'язаним із майновими, традиційно відносять тільки відносини, що вини- 
кають у зв'язку зі створенням і використанням результатів інтелектуальної діяльності.

Договір на надання оплатних освітніх послуг $€$ підставою виникнення й адміністративних правовідносин, пов'язаних 3 обов'язками студентів щодо дотримання правил поведінки, які передбачаються Статутом і Правилами внутрішнього розпорядку вищого навчального закладу. Крім того, договір породжує відносини й по вихованню, які своєю чергою передбачають поєднання методу «влади й підпорядкування» (адміністративне право) і морально-психологічних установок.

Висновки. Вищевикладене дозволяє зробити висновок про те, що договір на надання оплатних освітніх послуг є нетиповим цивільноправовим договором, який поєднує елементи цивільного й адміністративного права з переважанням цивільноправових засад. Такий висновок про правову природу договору підтверджується і судовою практикою. Як приклад, можна послатися на постанову Черкаського апеляційного суду, в якій визнано, що систематичне тлумачення Закону України «Про вищу освіту», котре передбачає укладення договору між особами, які навчаються, і освітньою установою, а також норми ЦК України «дозволяють визначити правову природу договору про підготовку фахівця з вищою освітою як комплексного договору, що містить елементи як цивільних, так і адміністративних правовідносин». Таким чином, умови договору не повинні суперечити нормам цивільного законодавства й нормам, які регулюють відносини в галузі освіти.

\section{Jimepamypa}

1. Про освіту : Закон України від 05 вересня 2017 р. № 2145-VIII / Верховна Рада України. Відомості Верховної Ради України. 2017. № 38-39. Ст. 380.

2. Про вищу освіту : Закон України від 01 липня 2014 р. № 1556-VII / Верховна Рада України. Відоло сті Верховної Ради України. 2017. № 37-38. Ст. 2004.

3. Цивільний кодекс України : Закон України від 16 січня 2003 р. № 435-IV / Верховна Рада України. Відолості Верховної Ради України. 2003. № 40-41. Ст. 356.

4. Голоденко I.О. Договір про надання освітніх послуг у цивільному праві України. Актуальні проблели приватного права : матеріали Всеукраїнської науково-практичної конференції, присвяченої пам'яті Ю.С. Червоного (до 90-річчя від дня його народження), м. Одеса, 15 грудня 2017 р. / упор. та відп. ред. I.C. Канзафарова, В.М. Зубар. Одеса : Астропринт, 2017. С. 88-94.

5. Деревянко Д.В. Щодо визначення понять «надання освітніх послуг» та «надання послуг у сфеpi освіти». Вісник Запорізького юридичного інститу ту Дніпропетровського державного університету внутрішніх справ. 2011. № 4 (57). С. 92-109.

6. Данилова Л.Я. Особенности правового регулирования отношений, возникающих при возмездном оказании образовательных услуг. Юридическое образование и наука: проблелы модернизации : Тези
Міжнародної науково-практичної конференції. Харків, 2011. С. 15-41.

7. Волчанская Л.М. Динамика договора возмездного оказания образовательных услуг. Юридическое образование и наука. 2013. № 2. С. 57-63

8. Куров С.В. Особенности гражданско-правового регулирования возмездного оказания образовательных услуг. Право и образование. 2011. № 6. С. 2-37.

\section{Анотація}

Котенко О. М. Правове регулювання договору про надання платних освітніх послуг у сфері вищої освіти. - Стаття.

У статті розглянуто правову регламентацію договору про надання платних освітніх послуг у сфері вищої освіти, оскільки вдосконалення системи освіти й освітнього законодавства представляється найважливішим завданням соціально-економічного розвитку й одним із пріоритетів сучасної державної політики є необхідність розвитку нормативно-правової бази у сфері освіти й надання платних освітніх послуг.

Водночас слід зазначити, що проблеми правової характеристики договору про надання платних освітніх послуг у сфері вищої освіти в різних роботах так i не розв'язані, що дозволяє варіювати такі послуги в різних галузях права, применшуючи значення в їх визначенні, що ще раз доводить необхідність проведення дослідження.

У статті зазначається, що основним правом замовника за договором про надання платних освітніх послуг у сфері вищої освіти є все-таки право вимагати від виконавця надання освітніх послуг.

Крім цього, у роботі зазначається, що особи, які навчаються, вправі освоювати крім навчальних дисциплін за обраними напрямами підготовки (спеціальностями) будь-які інші навчальні дисципліни, що викладаються у виші, в порядку, передбаченому його статутом і договором; брати участь в обговоренні й розв'язанні найважливіших питань діяльності вищого навчального закладу, в тому числі через його громадські організації та органи управління; користуватися в державній установі бібліотеками, інформаційними фондами, послугами навчальних, наукових та інших підрозділів вищого навчального закладу в порядку, встановленому його статутом.

Не викликає сумнівів, що однією з ключових умов будь-якого договору, в тому числі й договору про надання платних освітніх послуг, є його предмет. У статті зазначено, що предметом договору є освітні послуги, які характеризуються тим, що діяльність виконавця втілюється не в реальному результаті, а в деякому нематеріальному результаті, виражається в знаннях, уміннях, досвіді й навичках, придбаних студентом в процесі й у результаті їх надання.

Дослідивши різні теоретичні думки й норми законодавства України з приводу правової природи договору про надання платних освітніх послуг у сфері вищої професійної освіти, виявлено, що майнові відносини у сфері надання платних освітніх послуг опосередковуються договором, що має цивільноправовий характер. У взаємини з освітніми організаціями громадяни вступають на строго добровільних засадах, що відповідає принципу свободи договору й нормам цивільного права.

Ключові слова: правова природа, освітні послуги, оплатний договір, принципи цивільного права, методи адміністративного регулювання. 


\section{Summary}

Kotenko O. M. Legal regulation of the agreement on the provision of paid educational services in the field of higher education. - Article.

The article considers the legal regulation of the agreement on the provision of paid educational services in the field of higher education. Since the improvement of the education system and educational legislation is the most important task of socio-economic development and one of the priorities of modern public policy is the need to develop the regulatory framework in the field of education and the provision of paid educational services.

At the same time, it should be noted that the problems of the legal characteristics of the contract for the provision of paid educational services in the field of higher education in various works have not been resolved, which allows to vary these services in most branches of law. the need for this study.

The article states that the main right of the customer under the contract for the provision of paid educational services in the field of higher education is still the right to require the contractor to provide educational services.

In addition, the paper notes that persons who study have the right to master in addition to academic disciplines in selected areas of training (specialties) any other academic disciplines taught in this university, in the manner prescribed by its charter and contract; to participate in the discussion and resolution of the most important issues of the university, including through its public organizations and governing bodies; to use libraries, information funds, services of educational, scientific and other subdivisions of a higher educational institution in a state institution in accordance with the procedure established by its charter.

There is no doubt that one of the key conditions of any contract, including the contract for the provision of paid educational services is its subject. The article states that the subject of this agreement are educational services, which are characterized by the fact that the activities of the performer are not embodied in a real result, but in some intangible result, expressed in knowledge, skills, experience and skills acquired by students in the process and as a result.

Examining various theoretical points of view and norms of Ukrainian legislation on the legal nature of the contract for paid educational services in higher professional education, it was found that property relations in the field of paid educational services are mediated by the contract, which are civil in nature. In relations with educational organizations, citizens enter on a strictly voluntary basis, in accordance with the principle of freedom of contract and the rules of civil law.

Key words: legal nature, educational services, payment agreement, principles of civil law, methods of administrative regulation. 